\title{
hsa-miR-520h downregulates ABCG2 in pancreatic cancer cells to inhibit migration, invasion, and side populations
}

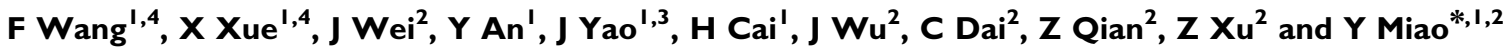 \\ 'Laboratory of General Surgery, The First Affiliated Hospital of Nanjing Medical University, Nanjing 210009 , PR China; ${ }^{2}$ Center for Pancreatic Surgery, \\ The First Affiliated Hospital of Nanjing Medical University, Nanjing 210009 , PR China; ${ }^{3}$ Department of General Surgery, The First Affiliated Hospital \\ of Yangzhou University, Yangzhou 22500 I, PR China
}

BACKGROUND: Expression of ABCG2 is normally absent or low in the pancreas, but high in human pancreatic cancer cells. The mechanism by which ABCG2 is altered in human cancers remains unknown.

METHODS: We investigated ABCG2 expression in four pancreatic cancer cell lines, and used three microRNA (miRNA) target prediction programmes, and information from the existing literature to predict and identify hsa-miR-520h as an miRNA that targets ABCG2. The function of this miRNA was investigated by transient transfection of the pancreatic cancer cell line PANC-I with oligonucleotides that mimic hsa-miR-520h.

RESULTS: Results showed that both mRNA and protein levels of ABCG2 were reduced, indicating that it was a target of hsa-miR-520h. Introduction of hsa-miR-520h mimics into PANC-I cells also resulted in inhibition of cell migration and invasion, and reduction of side population cells. Cell proliferation, cell cycle progression and apoptosis were not affected.

CONCLUSIONS: We propose that the effects of hsa-miR-520h may be, at least in part, caused by its regulation of ABCG2. Thus, our findings provide a new insight into the function of miRNA in the regulation of ABCG2 expression in pancreatic cancer. Gene therapy using miRNA mimics may therefore be useful as a pancreatic cancer therapy.

British Journal of Cancer (2010) 1 03, 567-574. doi:I0.1038/sj.bjc.6605724 www.bjcancer.com

Published online 13 July 2010

(C) 2010 Cancer Research UK

Keywords: miRNA; ABCG2; migration; invasion; side population cells

Pancreatic cancer is the fourth leading cause of cancer-related death in Western countries and has the lowest patient survival rate of any solid cancer (Jemal et al, 2009). One of the main reasons for its mortality is that pancreatic cancer cells have a high potential for invasion and metastasis. Although invasion and migration are the overwhelming causes of mortality in patients with solid tumours, our understanding of their molecular determinants is limited (Fidler, 2003; Weigelt et al, 2005; Gupta and Massagué, 2006). Studies on tumour invasion and metastasis have revealed a critical role for microRNAs (miRNAs), which are small, endogenous noncoding RNAs that post-transcriptionally regulate a variety of genes pivotal for invasion or metastasis (Lim et al, 2005; Dalmay and Edwards, 2006; Kim et al, 2008).

Expression of ABCG2, also known as breast cancer resistance protein, is normally absent or low in the pancreas (Doyle et al, 1998; Fetsch et al, 2006). However, recent studies show that ABCG2 is overexpressed in pancreatic cancer cells (König et al, 2005; Olempska et al, 2007; Guo et al, 2009), in which it alters the cellular epigenetic programming to promote cell survival. Moreover, ABCG2 expression is high in side-population cells of pancreatic and other tumour cell lines, as well as in primary tumour samples (Hirschmann-Jax et al, 2004; Seigel et al, 2005; Haraguchi et al, 2006; Shi et al, 2008; Sung et al, 2008; Dou et al, 2009; Wang et al, 2009; Yajima et al, 2009), in which it is likely to have a key role in

\footnotetext{
*Correspondence: Dr Y Miao; E-mail: miaoyi@njmu.edu.cn

${ }^{4}$ These authors contributed equally to this study.

Received 16 February 2010; revised 10 May 2010; accepted 13 May 2010; published online 13 July 2010
}

xenobiotic protection, and acts as a marker of side-population cells. However, the mechanism by which ABCG2 becomes overexpressed in human cancers remains unknown, and relatively little is known about the mechanisms that normally regulate ABCG2 expression. Previous studies suggested that it may be regulated by DNA methylation (To et al, 2006; Turner et al, 2006), 5 -untranslated region (UTR) variation (Nakanishi et al, 2006), or histone modification (To et al, 2008a). Cytokines and growth factors (Evseenko et al, 2007; Yin et al, 2008), such as transforming growth factor- $\beta$, tumour necrosis factor- $\alpha$, interleukin $1-\beta$, and insulin-like growth factor 2, are proposed to be involved in ABCG2 regulation. The surface protein levels of ABCG2 do not correlate well with mRNA levels in pancreatic cancer cells (Guo et al, 2009), suggesting that protein-regulatory mechanisms, such as posttranscriptional regulation, post-translational modifications, proteolysis, or sequestration in cell compartments, may affect the protein, without changing the transcript levels. Therefore, additional investigations of ABCG2 expression mechanisms in pancreatic cancer are needed.

miRNAs regulate gene expression post-transcriptionally, by pairing with complementary nucleotide sequences in the $3^{\prime}$-UTR of specific target mRNAs (Pillai, 2005; Zamore and Haley, 2005). They also have an important role in regulating diverse cellular processes, including proliferation, differentiation, cell cycle regulation, and apoptosis (Liao et al, 2008; Wang et al, 2008, 2009, 2009; Bandi et al, 2009; Bhattacharya et al, 2009; Noonan et al, 2009; Ribas et al, 2009; Saito et al, 2009; Song et al, 2009; Ostenfeld et al, 2010; Spizzo et al, 2010). miRNAs can function either as tumour suppressors or as oncogenes, depending on the genes they 
target (Si et al, 2007; Welch et al, 2007; Aguda et al, 2008; Grady et al, 2008; Agirre et al, 2009; Furuta et al, 2009; Gandellini et al, 2009; Hoffman et al, 2009; Hurst et al, 2009; Lee et al, 2009; Sachdeva et al, 2009; Tsang and Kwok, 2009; Wu et al, 2009; Aqeilan et al, 2010). Deletion or loss of a suppressive miRNA results in overexpression of target oncogenes, or conversely, activation or overexpression of an oncogenic miRNA results in silencing of tumour-suppressor targets. Thus, oncogenic miRNAs are usually overexpressed in tumours. For example, miR-125a, miR-10a, miR-21, miR-222, miR-125b, miR-7, miR-452, miR-10b, miR-373, and miR-520c induce cell migration and invasion when overexpressed in tumours or tumour cell lines (Ma et al, 2007; Asangani et al, 2008; Huang et al, 2008; Yan et al, 2008; Zhang et al, 2008; Zhu et al, 2008; Cowden Dahl et al, 2009; Qian et al, 2009; Veerla et al, 2009; Weiss et al, 2009). In contrast, suppressive miRNAs such as miR-193b, miR-122, miR-15a, miR-16-1, miR-200, miR-221, miR-126*, miR-335, miR-146a, and miR-29c lead to carcinogenesis, tumour growth, and invasion when downregulated (le Sage et al, 2007; Bonci et al, 2008; Korpal et al, 2008; Lin et al, 2008; Musiyenko et al, 2008; Sengupta et al, 2008; Tavazoie et al, 2008; Coulouarn et al, 2009; Li et al, 2009).

In this study, on the basis of previous reports (Liao et al, 2008; To et al, 2008b), we investigated whether hsa-miR-520h targets ABCG2 mRNA. We also investigated the role of hsa-miR-520h in proliferation, cell cycle progression, apoptosis, migration, and invasion in PANC-1 cells. As side-population cells of pancreatic cancer that overexpress ABCG2 have been identified as promoting carcinogenesis (Ho et al, 2007; Shi et al, 2008; Dou et al, 2009; Wang et al, 2009), we also investigated the effects of hsa-miR-520h on these cells. We determined whether the effects of hsa-miR-520h are linked to downregulation of ABCG2 expression. On the basis of our findings, we propose a model explaining how loss of hsa-miR520h expression and subsequent activation of ABCG2 expression are critical events in the invasion and migration of human pancreatic cancer cells.

\section{MATERIALS AND METHODS}

\section{Cell culture}

Human pancreatic cancer cell lines BxPC-3, CFPAC-1, PANC-1, and SW1990 were obtained from Shanghai Cell Bank (Shanghai, China), and propagated in our laboratory by culturing in Dulbecco's modified Eagle's medium (DMEM, Invitrogen, Carlsbad, CA, USA) supplemented with $10 \%$ fetal bovine serum (FBS, Sigma, St Louis, MO, USA), $2 \mathrm{~mm}$ glutamine, $100 \mu \mathrm{g} \mathrm{ml}^{-1}$ penicillin, and $100 \mu \mathrm{g} \mathrm{ml}^{-1}$ streptomycin. All cells were incubated at $37^{\circ} \mathrm{C}$ in a humidified chamber supplemented with $5 \% \mathrm{CO}_{2}$.

\section{Target prediction}

Three online programs, miRanda (http://www.microrna.org/ microrna/home.do), TargetScan (http://www.targetscan.org), and TarBase (http://diana.cslab.ece.ntua.gr/tarbase), were used in combination with previous reports, for predicting miRNAs that might target ABCG2. PANC-1 cells overexpressing ABCG2 were used for target miRNA verification.

\section{miRNA transfection}

miRNAs were designed and synthesised by Genepharma (Shanghai, China). hsa-miR-520h mimics were sense: $5^{\prime}$-ACAAAGUGCUUCC CUUUAGAGU- $3^{\prime}$ and anti-sense: $5^{\prime}$-UCUAAAGGGAAGCACUUU GUUU- $3^{\prime}$. Negative controls were sense: $5^{\prime}$-UUCUCCGAACGUGU CACGUTT- $3^{\prime}$ and anti-sense: $5^{\prime}$-ACGUGACACGUUCGGAGAATT- $3^{\prime}$. MicroRNA transfection was performed using Lipofectamine 2000 (Invitrogen). PANC-1 cells were grown in six-well plates to $50 \%$ confluence before transfection. Total RNA and protein were extracted at $24 \mathrm{~h}$ post-transfection and used for quantitative real-time PCR (qRT-PCR) and western blot analysis. Transfections were the following: hsa-miR-520h mimics (miR-520h), negative control miRNA mimics (NC) and blank control culture medium (Mock).

\section{qRT - PCR and western blot}

Total RNA was extracted from cultured or transfected cells using Trizol (Invitrogen). ABCG2 mRNA was detected by qRT-PCR
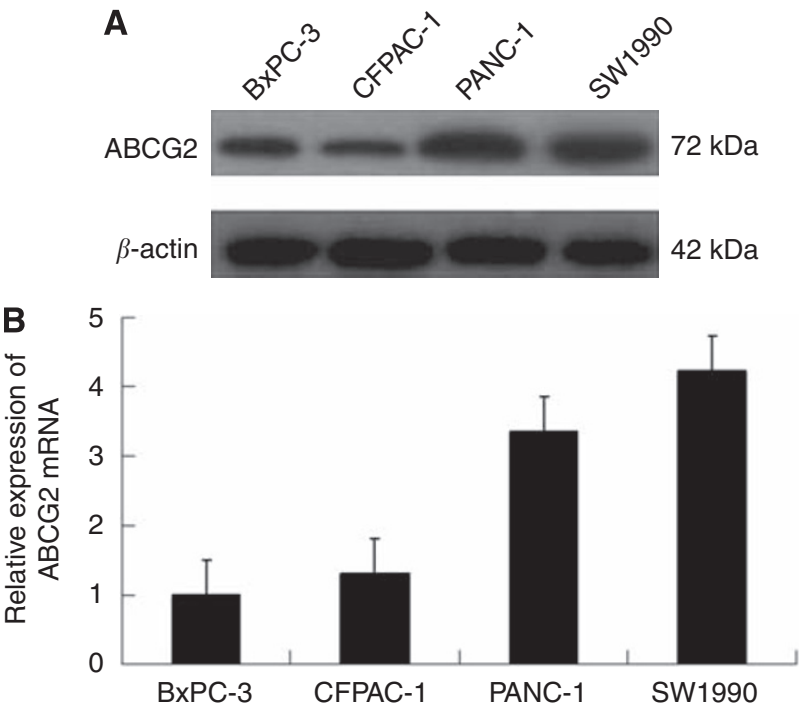

Figure I Expression of ABCG2 in four pancreatic cancer cell lines (A) Western blot. $\beta$-Actin was used as an internal loading control. (B) Quantitative real-time PCR for relative expression of ABCG2 with normalisation to $\beta$-actin
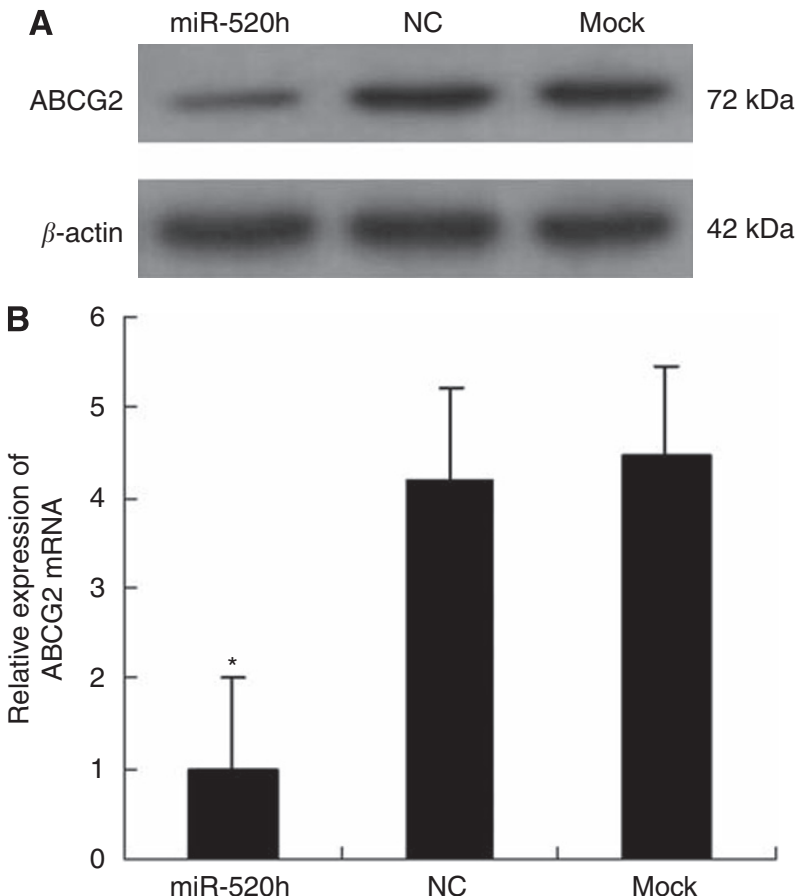

Figure 2 hsa-miR-520h targets $A B C G 2$. (A) The $A B C G 2$ protein in PANC-I cells by western blot at $24 \mathrm{~h}$ post-transfection of hsa-miR-520h mimic. $\beta$-Actin was used as an internal loading control. hsa-miR-520h mimics (miR-520h), negative control miRNA mimics (NC), and blank control culture medium (mock). (B) ABCG2 mRNA levels were analysed by qRT-PCR at $24 \mathrm{~h}$ post-transfection of hsa-miR-520h mimic and normalised to $\beta$-actin. $* P<0.05$. 
(Takara, Dalian, China) and normalised to $\beta$-actin. Polymerase chain reaction primers used were the following: ABCG2 sense: $5^{\prime}-$ AATACATCAGCGGATACTACAGAG-3' ${ }^{\prime}$, anti-sense: $5^{\prime}$-AGCCACC ATCATAAGGGT AAACAT- $3^{\prime} ; \beta$-actin sense: $5^{\prime}$-AGAAAATCTGGC ACCACACC-3', anti-sense: 5'-TAGCACAGC CTGGATAGCAA- $3^{\prime}$. Reactions were performed using an ABI PRISM 7000 Sequence Detection system (Applied Biosystems, Foster City, CA, USA). Cultured or transfected cells were lysed using RIPA buffer with $1 \%$ PMSF. Protein concentration was estimated using a BCA kit (Keygen, Nanjing, China). Protein was resolved with 10\% SDSPAGE and transferred to polyvinylidene difluoride (PVDF) membranes, which were blocked with $5 \%$ non-fat milk in Trisbuffered saline for $3 \mathrm{~h}$ and incubated overnight with primary antibodies against ABCG2 (Abcam, Cambridge, MA, USA) or $\beta$-actin (Santa Cruz, Santa Cruz, CA, USA). Membranes were incubated for $2 \mathrm{~h}$ with horseradish peroxidase-conjugated goat anti-rabbit or goat anti-mouse (Santa Cruz) secondary antibody and visualised with an electrochemiluminescence kit (Pierce, Rockford, IL, USA).

\section{Cell proliferation, cell cycle, and apoptosis analysis}

Cell proliferation was determined using an MTT assay. PANC-1 cells were seeded in 96-well culture plates (Costar, Cambridge) at a density of $1 \times 10^{3}$ cells per well, transfected with the indicated miRNA and incubated for $24 \mathrm{~h}$ before adding $10 \mu \mathrm{l}$ of MTT reagent to each well and incubating at $37^{\circ} \mathrm{C}$ for $4 \mathrm{~h}$; thereafter, the medium was replaced with $150 \mu \mathrm{l}$ dimethyl sulphoxide (DMSO) and oscillated for $10 \mathrm{~min}$. Viable cells were measured by absorbance at $490 \mathrm{~nm}$ wavelength using a microplate reader.

Cell cycle and apoptosis were assessed by flow cytometry (Becton Dickinson, San Jose, CA, USA). PANC-1 cells were grown and transfected as above. For cell cycle analysis, cells were collected, washed with phosphate-buffered saline (PBS) and fixed in ethanol at $-20^{\circ} \mathrm{C}$ overnight before being collected by centrifugation, washed with PBS, and resuspended in $500 \mu \mathrm{l}$ of PBS with $0.2 \%$ Triton X-100, $10 \mathrm{~mm}$ EDTA, $100 \mu \mathrm{g} \mathrm{ml}^{-1}$ RNase A, and $50 \mu \mathrm{g} \mathrm{ml}^{-1}$ propidium iodide (PI) at room temperature for $30 \mathrm{~min}$. For cell apoptosis, cells were collected, washed with PBS, suspended in $100 \mu \mathrm{l} 1 \times$ binding buffer, stained with $5 \mu \mathrm{l}$ annexinfluorescein isothiocyanate (FITC), and $5 \mu \mathrm{l} \mathrm{PI}$ at room temperature for $15 \mathrm{~min}$ in the dark.

\section{Cell migration and invasion analysis}

Cell migration and invasion were assayed using a chamber of $6.5 \mathrm{~mm}$ in diameter, with $8 \mu \mathrm{m}$ pore size (Corning, Corning, NY, USA). At $24 \mathrm{~h}$ post-transfection, PANC- 1 cells were added to the upper chamber, which was coated with $1 \mathrm{mg} \mathrm{ml}^{-1}$ matrigel for invasion assays, and $0.6 \mathrm{ml}$ of $10 \%$ FBS-DMEM was added to the lower chamber. Cells were incubated for $24 \mathrm{~h}$ at $37^{\circ} \mathrm{C}$, and nonmigrating or non-invading cells were removed with cotton swabs.
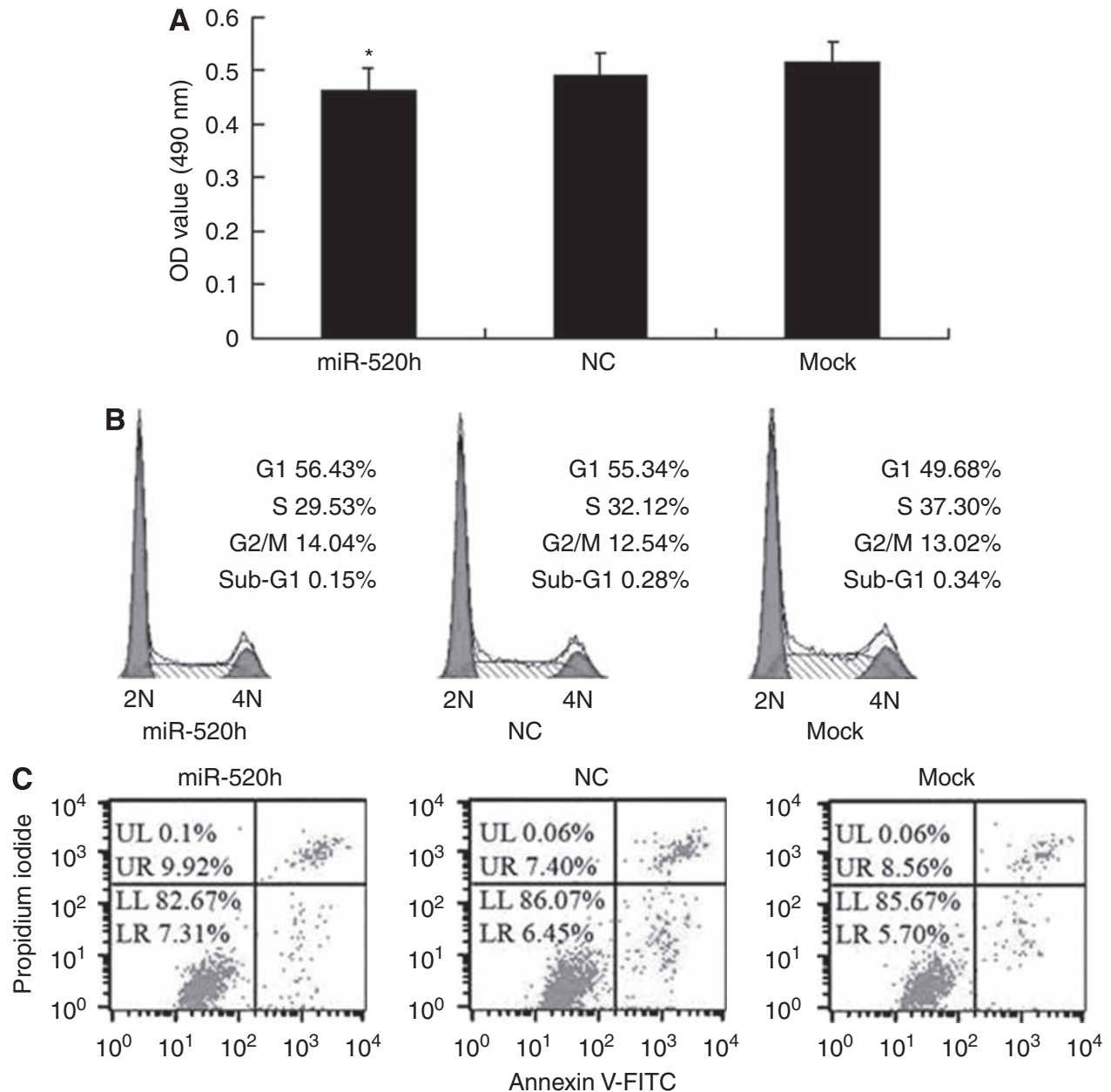

Figure 3 Effect of hsa-miR-520h on cell proliferation, cell cycle, and apoptosis of PANC-I cells. (A) The proliferation ability of PANC-I cells at $24 \mathrm{~h}$ post-transfection with hsa-miR-520h mimic was detected by MTT assay. The data are mean \pm s.d. from three independent experiments (*P $>0.05$, compared with controls). (B) Cell cycle analysis of PANC-I cells at $24 \mathrm{~h}$ post-transfection was analysed by flow cytometry. $2 \mathrm{~N}$ : cells have diploid DNA content; 4N: cells have tetraploid DNA content. (C) Apoptosis of PANC-I cells at $24 \mathrm{~h}$ post-transfection was monitored by flow cytometry. LR is indicative of apoptosis. 
Cells migrating to or invading the bottom of the membrane were stained with $0.1 \%$ crystal violet for $30 \mathrm{~min}$ at $37^{\circ} \mathrm{C}$, and washed with PBS. Stained cells were soaked in $33 \%$ ice-cold acetic acid and oscillated for $10 \mathrm{~min}$. Cell migration or invasion was assessed by absorbance at $570 \mathrm{~nm}$ wavelength using a microplate reader (Tecan, Shanghai, China).

\section{Side-population cell analysis}

For analysis of side-population cells, PANC-1 cells were transfected with miRNA for $24 \mathrm{~h}$, then incubated with Hoechst 33342 $\left(5 \mu \mathrm{mol} \mathrm{ml} l^{-1}\right.$, Sigma) for $90 \mathrm{~min}$ at $37^{\circ} \mathrm{C}$, either alone or in combination with $50 \mu \mathrm{mol}$ per $\mathrm{ml}$ verapamil. Cells were analysed in a FACS Vantage cell sorter (Becton Dickinson) using dualwavelength analysis (blue $425 \mathrm{~nm}$, red $675 \mathrm{~nm}$ ) after excitation with $350 \mathrm{~nm}$ UV light. Propidium iodide-positive cells were excluded.

\section{Statistical analysis}

Each experiment was conducted at least three times. All values were reported as mean \pm s.d. Differences between experimental groups and controls were assessed by Student's $t$-test using Excel software. $P<0.05$ was considered statistically significant.

\section{RESULTS}

\section{Pancreatic cancer cell lines expressed variable levels of ABCG2}

Recent studies have revealed that ABCG2 is overexpressed in many human cancers. Therefore, we checked the expression of ABCG2 in four human malignant pancreatic cancer cell lines: BxPC-3, CFPAC-1, PANC-1, and SW1990. BxPC-3 and CFPAC-1 are lowgrade cancer cell lines, and PANC-1 and SW1990 are high-grade lines. Western blot analysis showed that ABCG2 was overexpressed in PANC-1 and SW1990 cells, and underexpressed in BxPC-3 and CFPAC-1 cells (Figure 1A). These results were confirmed by qRT - PCR analysis (Figure 1B).

\section{hsa-miR-520h targets ABCG2}

Using miRNA target predicting programmes and previous reports, we hypothesised that the miRNA hsa-miR-520 h targeted ABCG2, and we chose PANC-1 cells to test our hypothesis. To verify our predicted target of hsa-miR-520h, we transfected PANC-1 cells with hsa-miR-520h mimics (miR-520h), negative control miRNA mimics (NC), and blank control culture medium (mock). Western blot analysis showed that, at $24 \mathrm{~h}$ post-transfection, overexpression of hsa-miR-520h resulted in a significant decrease of endogenous ABCG2 protein levels, compared with cells transformed with NC or
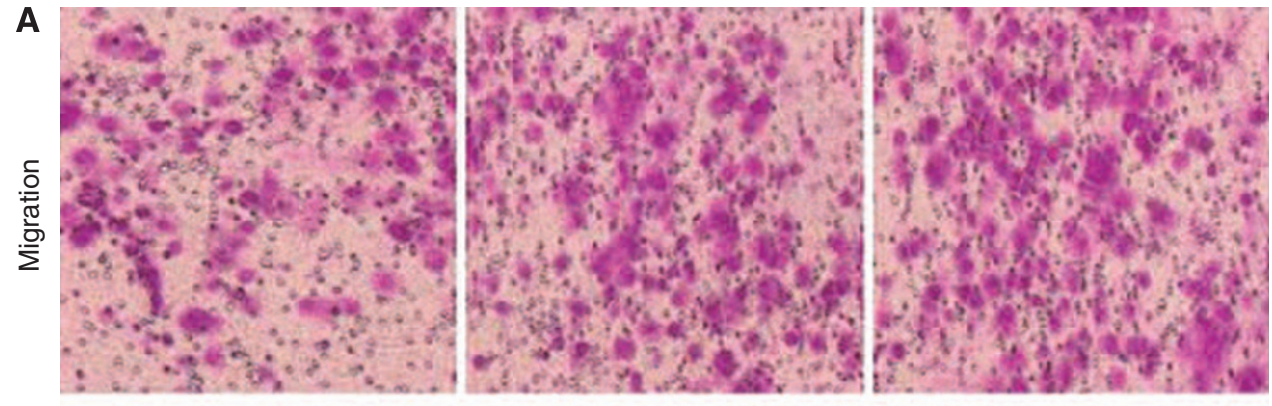

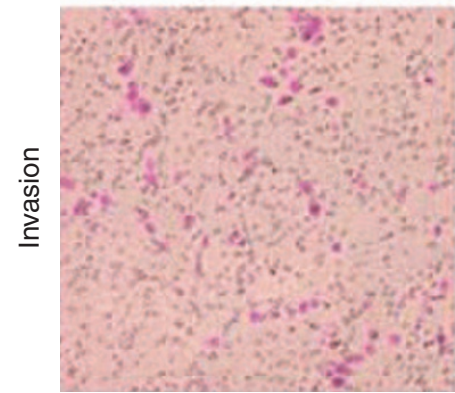

miR-520h

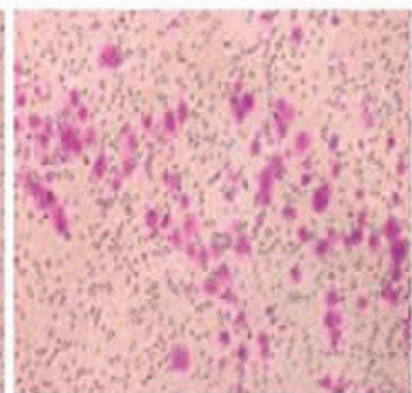

NC

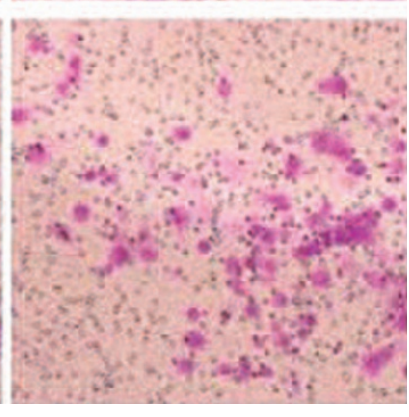

Mock
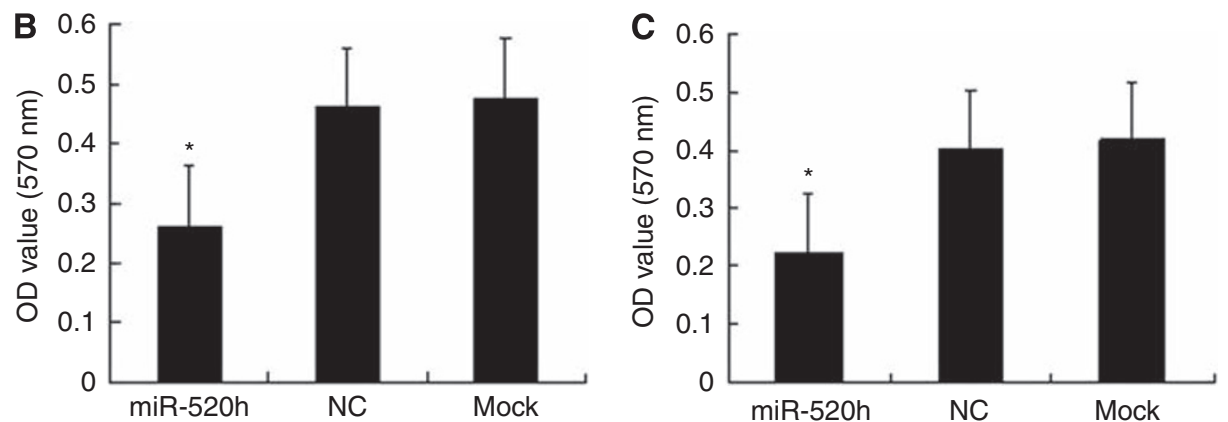

Figure 4 Overexpression of hsa-miR-520h inhibits cell migration and invasion of PANC-I cells. PANC-I cells were transfected with hsa-miR-520h, NC, or mock-transfected, then subjected to transwell assays, as described in Materials and Methods. After $24 \mathrm{~h}$, cells were stained and measured. (A) Representative photographs of migrating or invading cells. (B, C) Average OD value of migration or invasion from three independent experiments \pm s.d. (B) Cell migration. (C) Cell invasion. ${ }^{*} P<0.05$. 
mock (Figure 2A). Inhibition of expression by miRNAs mediates mRNA levels; hence we used qRT-PCR to examine ABCG2's mRNA levels. Overexpression of hsa-miR-520h in PANC-1 cells led to a corresponding decrease of endogenous ABCG2 mRNA at $24 \mathrm{~h}$ post-transfection (Figure $2 \mathrm{~B}$ ). These observations suggested that hsa-miR-520h downregulates ABCG2 expression by inhibiting translation or causing mRNA instability. Taken together, these data indicate that hsa-miR-520h targets ABCG2.

\section{Effects of hsa-miR-520h on proliferation, cell cycle, and apoptosis}

To investigate whether hsa-miR-520h influenced cell proliferation, cell cycle, or apoptosis of PANC-1 cells by inhibiting translation of the indicated target ABCG2 mRNA, we transiently transfected PANC-1 cells with hsa-miR-520h mimics for $24 \mathrm{~h}$. Ectopic expression of hsa-miR-520h had no significant inhibition on cell proliferation compared with that of control groups (Figure 3A). The cell cycle distribution of transfected cells was examined by flow cytometry, with no significant G0/G1 accumulation phenotype in PANC-1 cells transfected with hsa-miR-520h (56.43\%) compared with NC (55.34\%) or mock (49.68\%) control-transfected cells (Figure 3B). We also examined the cell apoptosis of transfected cells by flow cytometry, and found no significant increase in apoptosis in PANC-1 cells transfected with hsa-miR$520 \mathrm{~h}(7.31 \%)$ compared with $\mathrm{NC}(6.45 \%)$ or mock $(5.70 \%)$ transfected cells (Figure 3C).

\section{hsa-miR-520h inhibits migration and invasion of PANC-1 cells}

To determine whether hsa-miR-520h and its target gene are associated with tumour migration and invasion, we transfected PANC-1 cells with hsa-miR-520h mimics or NC, or subjected them to mock transfection, and evaluated cell migration and invasion. As shown in Figure $4 \mathrm{~A}$ and $\mathrm{B}$, the migration ability of hsa-miR$520 \mathrm{~h}$ mimic-transfected cells was significantly decreased by $55 \%$, compared with that of controls. A matrigel invasion assay was performed in parallel to determine the effect of transfection with hsa-miR-520h mimics. As shown in Figure 4A and C, the invasion ability of hsa-miR-520h-transfected cells was significantly decreased by $53 \%$, compared with that of controls. Taken together, these results suggested that hsa-miR-520h functions as a potent suppressor of PANC-1 cell migration and invasion through downregulation of ABCG2 expression.

\section{hsa-miR-520h depletes the side population of PANC-1 cells}

Previous studies suggested that ABCG2 has an important role in the identity of side-population cells. Therefore, we examined the influence of hsa-miR-520h on the population of tumour cells that exclude Hoechst 33342 dye, a strategy that is used to identify side-population cells. Flow cytometry of hsa-miR-520h-transfected PANC-1 cells showed that the side population was $1.51 \%$, compared with $2.79 \%$ in NC-transfected and $3.06 \%$ in mock-transfected cells (Figure 5). These data indicated that
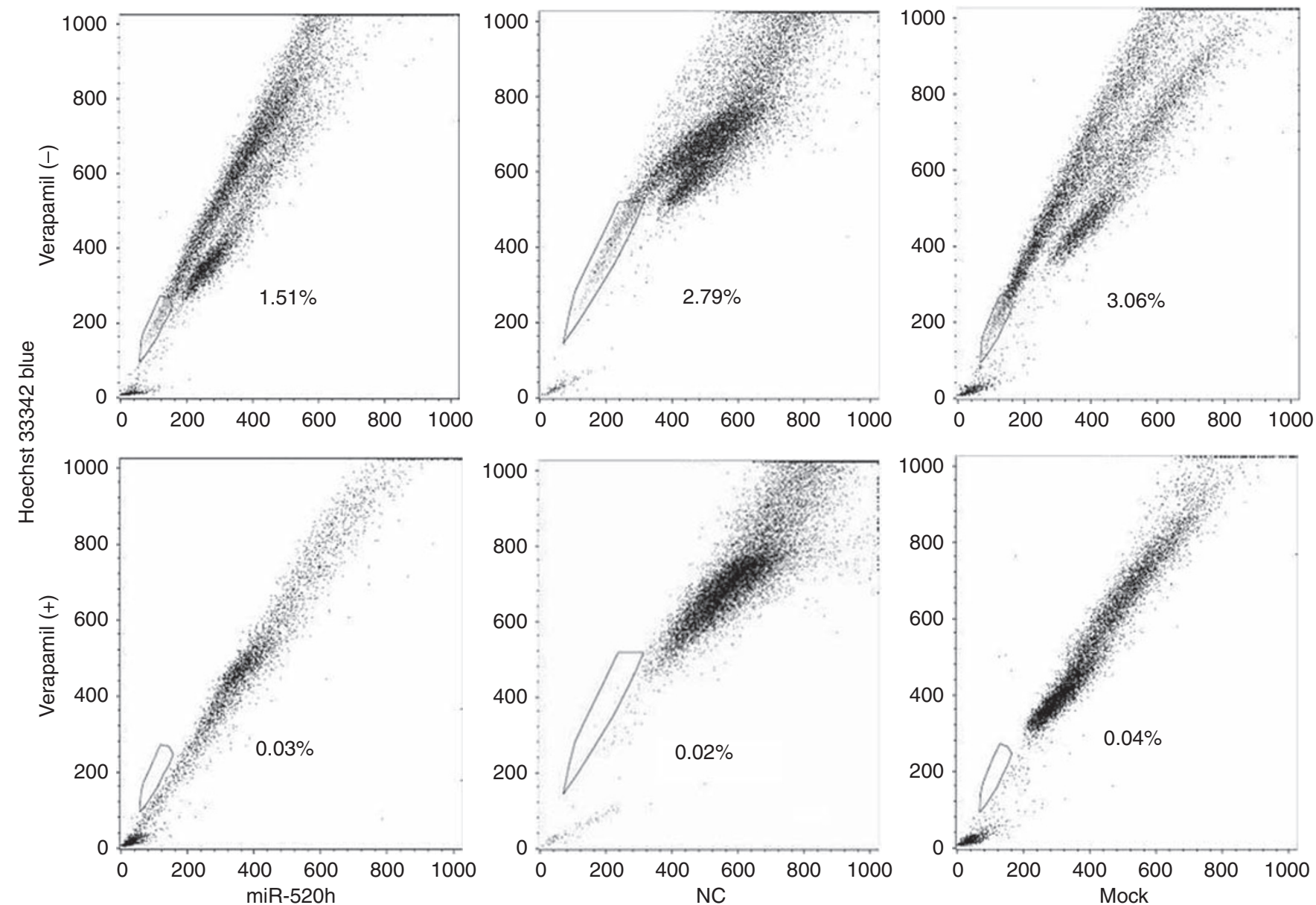

Hoechst 33342 red

Figure 5 Overexpression of hsa-miR-520h decreases the side-population compartment of PANC-I cells. Side-population cells of PANC-I cells transfected with hsa-miR-520h account for $1.51 \%$ of the total number of cells, compared with $2.79 \%$ for NC-treated, or $3.06 \%$ for mock-treated, as measured by FACS analysis. 
hsa-miR-520 h has a critical role in the identification of the side population, through downregulation of ABCG2 expression.

\section{DISCUSSION}

To investigate the interaction between miRNAs and their target genes in pancreatic cancer, we determined the expression levels of ABCG2 in four pancreatic cancer cell lines. Both western blot and qRT-PCR analysis showed that the cell lines expressed variable levels of ABCG2, with high expression in PANC-1 and SW1990 cells, and low expression in BxPC-3 and CFPAC-1 cells (Figure 1). We used miRNA target prediction programmes and previous studies to find an miRNA that potentially regulated ABCG2, and selected PANC-1 cells for verification using transfected miRNA mimics. In the transfected cells, ABCG2 was downregulated at both the mRNA and protein levels by the proposed target miRNA, hsa-miR-520h (Figure 2). These data suggested that ABCG2 is a target of hsa-miR-520h in pancreatic cells.

Overexpression of ABCG2 promotes migration and invasion in a variety of different tumour types (Mohan et al, 2006; Ho et al, 2007; Chiou et al, 2008; Okamoto et al, 2009). The mechanism by which ABCG2 becomes overexpressed is not entirely clear, but a possible mechanism is through miRNA regulation. MicroRNAs can function as tumour suppressors, oncogenes, or as promoters or suppressors of metastasis. We transfected hsa-miR-520h into PANC-1 cells and observed cell proliferation, cycle, apoptosis, migration, and invasion. Introduction of hsa-miR-520h resulted in a significant decrease in cell migration and invasion, but with no

\section{REFERENCES}

Agirre X, Vilas-Zornoza A, Jiménez-Velasco A, Martin-Subero JI, Cordeu L, Gárate L, San José-Eneriz E, Abizanda G, Rodríguez-Otero P, Fortes P, Rifón J, Bandrés E, Calasanz MJ, Martín V, Heiniger A, Torres A, Siebert R, Román-Gomez J, Prósper F (2009) Epigenetic silencing of the tumor suppressor microRNA Hsa-miR-124a regulates CDK6 expression and confers a poor prognosis in acute lymphoblastic leukemia. Cancer Res 69: $4443-4453$

Aguda BD, Kim Y, Piper-Hunter MG, Friedman A, Marsh CB (2008) MicroRNA regulation of a cancer network: consequences of the feedback loops involving miR-17-92, E2F, and Myc. Proc Natl Acad Sci USA 105: $19678-19683$

Aqeilan RI, Calin GA, Croce CM (2010) miR-15a and miR-16 - 1 in cancer: discovery, function and future perspectives. Cell Death Differ 17: $215-220$

Asangani IA, Rasheed SA, Nikolova DA, Leupold JH, Colburn NH, Post S, Allgayer H (2008) MicroRNA-21 (miR-21) post-transcriptionally downregulates tumor suppressor Pdcd4 and stimulates invasion, intravasation and metastasis in colorectal cancer. Oncogene 27: 2128-2136

Bandi N, Zbinden S, Gugger M, Arnold M, Kocher V, Hasan L, Kappeler A, Brunner T, Vassella E (2009) miR-15a and miR-16 are implicated in cell cycle regulation in a $\mathrm{Rb}$-dependent manner and are frequently deleted or down-regulated in non-small cell lung cancer. Cancer Res 69: 5553-5559

Bhattacharya R, Nicoloso M, Arvizo R, Wang E, Cortez A, Rossi S, Calin GA, Mukherjee P (2009) MiR-15a and MiR-16 Control Bmi-1 Expression in Ovarian Cancer. Cancer Res 69: 9090-9095

Bonci D, Coppola V, Musumeci M, Addario A, Giuffrida R, Memeo L, D’Urso L, Pagliuca A, Biffoni M, Labbaye C, Bartucci M, Muto G, Peschle C, De Maria R (2008) The miR-15a-miR-16-1 cluster controls prostate cancer by targeting multiple oncogenic activities. Nat Med 14: $1271-1277$

Chiou SH, Yu CC, Huang CY, Lin SC, Liu CJ, Tsai TH, Chou SH, Chien CS, $\mathrm{Ku} \mathrm{HH}$, Lo JF (2008) Positive correlations of Oct-4 and Nanog in oral cancer stem-like cells and high-grade oral squamous cell carcinoma. Clin Cancer Res 14: 4085-4095

Coulouarn C, Factor VM, Andersen JB, Durkin ME, Thorgeirsson SS (2009) Loss of miR-122 expression in liver cancer correlates with suppression of the hepatic phenotype and gain of metastatic properties. Oncogene 28: $3526-3536$ significant effects on cell proliferation, cell cycle distribution, or apoptosis (Figures 3 and 4). This is the first study to show that hsa-miR-520h inhibits migration and invasion in pancreatic cancer cells, through a possible mechanism of negative regulation of ABCG2 expression.

In this study, FACS analysis at $24 \mathrm{~h}$ after transfection of PANC-1 cells with miRNA mimics showed a remarkable decrease in the proportion of side-population cells (Figure 5). Therefore, we propose that hsa-miR-520h may have a critical role in carcinogenesis by way of affecting side-population cells by influencing ABCG2 expression. However, Patrawala et al (2005) reported that ABCG2-positive and -negative tumour cells have similar tumourigenicity; hence, the precise reasons why ABCG2 is associated with pancreatic cancer cells require further study.

In conclusion, we show that hsa-miR-520h has a key role not only in inhibiting migration and invasion, but also in decreasing the proportion of side-population cells of PANC-1. The possible mechanism of these effects may be through downregulation of ABCG2 expression. As no effective approaches for curing pancreatic cancer exist at present, we propose that gene therapy targeting hsa-miR-520h/ABCG2 should be investigated further as a potential alternative therapeutic strategy for pancreatic cancer.

\section{ACKNOWLEDGEMENTS}

This study was supported by a Natural Science Foundation of China grant (30972912).
Cowden Dahl KD, Dahl R, Kruichak JN, Hudson LG (2009) The epidermal growth factor receptor responsive miR-125a represses mesenchymal morphology in ovarian cancer cells. Neoplasia 11: 1208-1215

Dalmay T, Edwards DR (2006) MicroRNAs and the hallmarks of cancer. Oncogene 25: 6170-6175

Dou J, Wen P, Hu W, Li Y, Wu Y, Liu C, Zhao F, Hu K, Wang J, Jiang C, $\mathrm{He} X, \mathrm{Gu} N$ (2009) Identifying tumor stem-like cells in mouse melanoma cell lines by analyzing the characteristics of side population cells. Cell Biol Int 33: 807-815

Doyle LA, Yang W, Abruzzo LE, Krogmann T, Gao Y, Rishi AK, Ross DD (1998) A multidrug resistance transporter from human MCF-7 breast cancer cells. Proc Natl Acad Sci USA 95: 15665-15670

Evseenko DA, Paxton JW, Keelan JA (2007) Independent regulation of apical and basolateral drug transporter expression and function in placental trophoblasts by cytokines, steroids, and growth factors. Drug Metab Dispos 35: 595-601

Fetsch PA, Abati A, Litman T, Morisaki K, Honjo Y, Mittal K, Bates SE (2006) Localization of the ABCG2 mitoxantrone resistance-associated protein in normal tissues. Cancer Lett 235: 84-92

Fidler IJ (2003) The pathogenesis of cancer metastasis: the 'seed and soil' hypothesis revisited. Nat Rev Cancer 3: 453-458

Furuta M, Kozaki KI, Tanaka S, Arii S, Imoto I, Inazawa J (2009) miR-124 and miR-203 are epigenetically silenced tumor-suppressive microRNAs in hepatocellular carcinoma. Carcinogenesis 31(5): $766-776$

Gandellini P, Folini M, Longoni N, Pennati M, Binda M, Colecchia M, Salvioni R, Supino R, Moretti R, Limonta P, Valdagni R, Daidone MG, Zaffaroni N (2009) miR-205 exerts tumor-suppressive functions in human prostate through down-regulation of protein kinase Cepsilon. Cancer Res 69: 2287-2295

Grady WM, Parkin RK, Mitchell PS, Lee JH, Kim YH, Tsuchiya KD, Washington MK, Paraskeva C, Willson JK, Kaz AM, Kroh EM, Allen A, Fritz BR, Markowitz SD, Tewari M (2008) Epigenetic silencing of the intronic microRNA hsa-miR-342 and its host gene EVL in colorectal cancer. Oncogene 27: $3880-3888$

Guo J, Anderson MG, Tapang P, Palma JP, Rodriguez LE, Niquette A, Li J, Bouska JJ, Wang G, Semizarov D, Albert DH, Donawho CK, Glaser KB, Shah OJ (2009) Identification of genes that confer tumor cell resistance to the aurora B kinase inhibitor, AZD1152. Pharmacogenomics J 9: 90-102 
Gupta GP, Massagué J (2006) Cancer metastasis: building a framework. Cell 127: $679-695$

Haraguchi N, Utsunomiya T, Inoue H, Tanaka F, Mimori K, Barnard GF, Mori M (2006) Characterization of a side population of cancer cells from human gastrointestinal system. Stem Cells 24: 506-513

Hirschmann-Jax C, Foster AE, Wulf GG, Nuchtern JG, Jax TW, Gobel U, Goodell MA, Brenner MK (2004) A distinct 'side population' of cells with high drug efflux capacity in human tumor cells. Proc Natl Acad Sci USA 101: $14228-14233$

Ho MM, Ng AV, Lam S, Hung JY (2007) Side population in human lung cancer cell lines and tumors is enriched with stem-like cancer cells. Cancer Res 67: 4827-4833

Hoffman AE, Zheng T, Yi C, Leaderer D, Weidhaas J, Slack F, Zhang Y, Paranjape T, Zhu Y (2009) microRNA miR-196a-2 and breast cancer: a genetic and epigenetic association study and functional analysis. Cancer Res 69: 5970 - 5977

Huang Q, Gumireddy K, Schrier M, le Sage C, Nagel R, Nair S, Egan DA, Li A, Huang G, Klein-Szanto AJ, Gimotty PA, Katsaros D, Coukos G, Zhang L, Puré E, Agami R (2008) The microRNAs miR-373 and miR-520c promote tumour invasion and metastasis. Nat Cell Biol 10: 202-210

Hurst DR, Edmonds MD, Scott GK, Benz CC, Vaidya KS, Welch DR (2009) Breast cancer metastasis suppressor 1 up-regulates miR-146, which suppresses breast cancer metastasis. Cancer Res 69: 1279-1283

Jemal A, Siegel R, Ward E, Hao Y, Xu J, Thun MJ (2009) Cancer statistics, 2009. CA Cancer J Clin 59: 225-249

Kim S, Lee UJ, Kim MN, Lee EJ, Kim JY, Lee MY, Choung S, Kim YJ, Choi YC (2008) MicroRNA miR-199a* regulates the MET proto-Oncogene and the downstream extracellular signal-regulated kinase 2 (ERK2). J Biol Chem 283: $18158-18166$

König J, Hartel M, Nies AT, Martignoni ME, Guo J, Büchler MW, Friess H, Keppler D (2005) Expression and localization of human multidrug resistance protein (ABCC) family members in pancreatic carcinoma. Int J Cancer 115: 359-367

Korpal M, Lee ES, Hu G, Kang Y (2008) The miR-200 family inhibits epithelial-mesenchymal transition and cancer cell migration by direct targeting of E-cadherin transcriptional repressors ZEB1 and ZEB2. J Biol Chem 283: 14910 - 14914

le Sage C, Nagel R, Egan DA, Schrier M, Mesman E, Mangiola A, Anile C, Maira G, Mercatelli N, Ciafrè SA, Farace MG, Agami R (2007) Regulation of the $\mathrm{p} 27$ (Kipl) tumor suppressor by miR-221 and miR-222 promotes cancer cell proliferation. EMBO J 26: $3699-3708$

Lee KH, Chen YL, Yeh SD, Hsiao M, Lin JT, Goan YG, Lu PJ (2009) MicroRNA -330 acts as tumor suppressor and induces apoptosis of prostate cancer cells through E2F1-mediated suppression of Akt phosphorylation. Oncogene 28: $3360-3370$

Li XF, Yan PJ, Shao ZM (2009) Downregulation of miR-193b contributes to enhance urokinase-type plasminogen activator (uPA) expression and tumor progression and invasion in human breast cancer. Oncogene 28: $3937-3948$

Liao R, Sun J, Zhang L, Lou G, Chen M, Zhou D, Chen Z, Zhang S (2008) MicroRNAs play a role in the development of human hematopoietic stem cells. J Cell Biochem 104: 805-817

Lim LP, Lau NC, Garrett-Engele P, Grimson A, Schelter JM, Castle J, Bartel DP, Linsley PS, Johnson JM (2005) Microarray analysis shows that some microRNAs downregulate large numbers of target mRNAs. Nature 433: $769-773$

Lin SL, Chiang A, Chang D, Ying SY (2008) Loss of mir-146a function in hormone-refractory prostate cancer. RNA 14: 417-424

Ma L, Teruya-Feldstein J, Weinberg RA (2007) Tumour invasion and metastasis initiated by microRNA-10b in breast cancer. Nature 449: 682-688

Mohan A, Kandalam M, Ramkumar HL, Gopal L, Krishnakumar S (2006) Stem cell markers: ABCG2 and MCM2 expression in retinoblastoma. Br J Ophthalmol 90: 889-893

Musiyenko A, Bitko V, Barik S (2008) Ectopic expression of miR-126*, an intronic product of the vascular endothelial EGF-like 7 gene, regulates prostein translation and invasiveness of prostate cancer LNCaP cells. J Mol Med 86: 313-322

Nakanishi T, Bailey-Dell KJ, Hassel BA, Shiozawa K, Sullivan DM, Turner J, Ross DD (2006) Novel $5^{\prime}$ untranslated region variants of BCRP mRNA are differentially expressed in drug-selected cancer cells and in normal human tissues: implications for drug resistance, tissue-specific expression, and alternative promoter usage. Cancer Res 66: 5007-5011

Noonan EJ, Place RF, Pookot D, Basak S, Whitson JM, Hirata H, Giardina C, Dahiya R (2009) miR-449a targets HDAC-1 and induces growth arrest in prostate cancer. Oncogene 28: 1714-1724
Okamoto A, Chikamatsu K, Sakakura K, Hatsushika K, Takahashi G, Masuyama K (2009) Expansion and characterization of cancer stem-like cells in squamous cell carcinoma of the head and neck. Oral Oncol 45: $633-639$

Olempska M, Eisenach PA, Ammerpohl O, Ungefroren H, Fandrich F, Kalthoff H (2007) Detection of tumor stem cell markers in pancreatic carcinoma cell lines. Hepatobiliary Pancreat Dis Int 6: $92-97$

Ostenfeld MS, Bramsen JB, Lamy P, Villadsen SB, Fristrup N, Sørensen KD, Ulhøi B, Borre M, Kjems J, Dyrskjøt L, Orntoft TF (2010) miR-145 induces caspase-dependent and -independent cell death in urothelial cancer cell lines with targeting of an expression signature present in Ta bladder tumors. Oncogene 29: 1073-1084

Patrawala L, Calhoun T, Schneider-Broussard R, Zhou J, Claypool K, Tang DG (2005) Side population is enriched in tumorigenic, stem-like cancer cells, whereas ABCG2+ and ABCG2- cancer cells are similarly tumorigenic. Cancer Res 65: 6207-6219

Pillai RS (2005) MicroRNA function: multiple mechanisms for a tiny RNA? RNA 11: $1753-1761$

Qian B, Katsaros D, Lu L, Preti M, Durando A, Arisio R, Mu L, Yu H (2009) High miR-21 expression in breast cancer associated with poor diseasefree survival in early stage disease and high TGF-betal. Breast Cancer Res Treat 117: $131-140$

Ribas J, Ni X, Haffner M, Wentzel EA, Salmasi AH, Chowdhury WH, Kudrolli TA, Yegnasubramanian S, Luo J, Rodriguez R, Mendell JT, Lupold SE (2009) miR-21: an androgen receptor-regulated microRNA that promotes hormone-dependent and hormone-independent prostate cancer growth. Cancer Res 69: 7165-7169

Sachdeva M, Zhu S, Wu F, Wu H, Walia V, Kumar S, Elble R, Watabe K, Mo YY (2009) p53 represses c-Myc through induction of the tumor suppressor miR-145. Proc Natl Acad Sci USA 106: 3207-3212

Saito Y, Suzuki H, Tsugawa H, Nakagawa I, Matsuzaki J, Kanai Y, Hibi T (2009) Chromatin remodeling at Alu repeats by epigenetic treatment activates silenced microRNA-512-5p with downregulation of Mcl-1 in human gastric cancer cells. Oncogene 28: 2738-2744

Seigel GM, Campbell LM, Narayan M, Gonzalez-Fernandez F (2005) Cancer stem cell characteristics in retinoblastoma. Mol Vis 11: 729-737

Sengupta S, den Boon JA, Chen IH, Newton MA, Stanhope SA, Cheng YJ, Chen CJ, Hildesheim A, Sugden B, Ahlquist P (2008) MicroRNA 29c is down-regulated in nasopharyngeal carcinomas, up-regulating mRNAs encoding extracellular matrix proteins. Proc Natl Acad Sci USA 105: $5874-5878$

Shi GM, Xu Y, Fan J, Zhou J, Yang XR, Qiu SJ, Liao Y, Wu WZ, Ji Y, Ke AW, Ding ZB, He YZ, Wu B, Yang GH, Qin WZ, Zhang W, Zhu J, Min ZH, Wu ZQ (2008) Identification of side population cells in human hepatocellular carcinoma cell lines with stepwise metastatic potentials. J Cancer Res Clin Oncol 134: $1155-1163$

Si ML, Zhu S, Wu H, Lu Z, Wu F, Mo YY (2007) miR-21-mediated tumor growth. Oncogene 26: 2799-2803

Song B, Wang Y, Xi Y, Kudo K, Bruheim S, Botchkina GI, Gavin E, Wan Y, Formentini A, Kornmann M, Fodstad O, Ju J (2009) Mechanism of chemoresistance mediated by miR-140 in human osteosarcoma and colon cancer cells. Oncogene 28: 4065-4074

Spizzo R, Nicoloso MS, Lupini L, Lu Y, Fogarty J, Rossi S, Zagatti B, Fabbri M, Veronese A, Liu X, Davuluri R, Croce CM, Mills G, Negrini M, Calin GA (2010) miR-145 participates with TP53 in a death-promoting regulatory loop and targets estrogen receptor-alpha in human breast cancer cells. Cell Death Differ 17: 246-254

Sung JM, Cho HJ, Yi H, Lee CH, Kim HS, Kim DK, Abd El-Aty AM, Kim JS, Landowski CP, Hediger MA, Shin HC (2008) Characterization of a stem cell population in lung cancer A549 cells. Biochem Biophys Res Commun 371: $163-167$

Tavazoie SF, Alarcón C, Oskarsson T, Padua D, Wang Q, Bos PD, Gerald WL, Massagué J (2008) Endogenous human microRNAs that suppress breast cancer metastasis. Nature 451: 147-152

To KK, Polgar O, Huff LM, Morisaki K, Bates SE (2008a) Histone modifications at the ABCG2 promoter following treatment with histone deacetylase inhibitor mirror those in multidrug-resistant cells. Mol Cancer Res 6: 151-164

To KK, Zhan Z, Bates SE (2006) Aberrant promoter methylation of the ABCG2 gene in renal carcinoma. Mol Cell Biol 26: 8572-8585

To KK, Zhan Z, Litman T, Bates SE (2008b) Regulation of ABCG2 expression at the $3^{\prime}$ untranslated region of its mRNA through modulation of transcript stability and protein translation by a putative microRNA in the S1 colon cancer cell line. Mol Cell Biol 28: $5147-5161$ 
Tsang WP, Kwok TT (2009) The miR-18a* microRNA functions as a potential tumor suppressor by targeting on K-Ras. Carcinogenesis 30: 953 - 959

Turner JG, Gump JL, Zhang C, Cook JM, Marchion D, Hazlehurst L, Munster P, Schell MJ, Dalton WS, Sullivan DM (2006) ABCG2 expression, function, and promoter methylation in human multiple myeloma. Blood 108: $3881-3889$

Veerla S, Lindgren D, Kvist A, Frigyesi A, Staaf J, Persson H, Liedberg F, Chebil G, Gudjonsson S, Borg A, Månsson W, Rovira C, Höglund M (2009) MiRNA expression in urothelial carcinomas: important roles of miR-10a, miR-222, miR-125b, miR-7 and miR-452 for tumor stage and metastasis, and frequent homozygous losses of miR-31. Int J Cancer 124: $2236-2242$

Wang P, Zou F, Zhang X, Li H, Dulak A, Tomko Jr RJ, Lazo JS, Wang Z, Zhang L, Yu J (2009) microRNA-21 negatively regulates Cdc25A and cell cycle progression in colon cancer cells. Cancer Res 69: 8157-8165

Wang Q, Li YC, Wang J, Kong J, Qi Y, Quigg RJ, Li X (2008) miR-17-92 cluster accelerates adipocyte differentiation by negatively regulating tumor-suppressor Rb2/p130. Proc Natl Acad Sci USA 105: 2889-2894

Wang X, Wang HK, McCoy JP, Banerjee NS, Rader JS, Broker TR, Meyers C Chow LT, Zheng ZM (2009) Oncogenic HPV infection interrupts the expression of tumor-suppressive miR-34a through viral oncoprotein E6. RNA 15: $637-647$

Wang YH, Li F, Luo B, Wang XH, Sun HC, Liu S, Cui YQ, Xu XX (2009) A side population of cells from a human pancreatic carcinoma cell line harbors cancer stem cell characteristics. Neoplasma 56: $371-378$

Weigelt B, Peterse JL, van 't Veer LJ (2005) Breast cancer metastasis: markers and models. Nat Rev Cancer 5: 591-602
Weiss FU, Marques IJ, Woltering JM, Vlecken DH, Aghdassi A, Partecke LI, Heidecke CD, Lerch MM, Bagowski CP (2009) Retinoic acid receptor antagonists inhibit miR-10a expression and block metastatic behavior of pancreatic cancer. Gastroenterology 137: 2136-2145

Welch C, Chen Y, Stallings RL (2007) MicroRNA-34a functions as a potential tumor suppressor by inducing apoptosis in neuroblastoma cells. Oncogene 26: $5017-5022$

Wu H, Zhu S, Mo YY (2009) Suppression of cell growth and invasion by miR-205 in breast cancer. Cell Res 19: 439-448

Yajima T, Ochiai H, Uchiyama T, Takano N, Shibahara T, Azuma T (2009) Resistance to cytotoxic chemotherapy-induced apoptosis in side population cells of human oral squamous cell carcinoma cell line Ho1-N-1. Int J Oncol 35: 273-280

Yan LX, Huang XF, Shao Q, Huang MY, Deng L, Wu QL, Zeng YX, Shao JY (2008) MicroRNA miR-21 overexpression in human breast cancer is associated with advanced clinical stage, lymph node metastasis and patient poor prognosis. RNA 14: $2348-2360$

Yin L, Castagnino P, Assoian RK (2008) ABCG2 expression and side population abundance regulated by a transforming growth factor betadirected epithelial-mesenchymal transition. Cancer Res 68: 800-807

Zamore PD, Haley B (2005) Ribo-gnome: the big world of small RNAs. Science 309: $1519-1524$

Zhang Z, Li Z, Gao C, Chen P, Chen J, Liu W, Xiao S, Lu H (2008) miR-21 plays a pivotal role in gastric cancer pathogenesis and progression. Lab Invest 88: $1358-1366$

Zhu S, Wu H, Wu F, Nie D, Sheng S, Mo YY (2008) MicroRNA-21 targets tumor suppressor genes in invasion and metastasis. Cell Res 18: $350-359$ 